\title{
DETERMINAN MINAT NASABAH PENGGUNA JASA RAHN DAN IJARAH PADA KANTOR CABANG PEGADAIAN SYARIAH MADIUN
}

\author{
Nik Amah ${ }^{1}$ \\ * Pendidikan Akuntansi, FKIP, Universitas PGRI Madiun \\ *nikamah@unipma.ac.id ${ }^{l}$
}

\begin{abstract}
This study aims to examine the determinants of customers interest who use rahn and ijarah services at the branch offices of Syariah Madiun branch covering the principles of syariah, ujrah, and service. Sampling was conducted by Accidental Sampling technique to get sample of 227 respondents. Data collection use questionnaires. The analysis method used in this research is Multiple Linear Regression Analysis. The result of the research shows that: (1) the application of sharia principle influences the customer interest who use rahn and ijarah service, (2) ujrah does not affect the customers interest who use rahn and ijarah services, (3) the service influences customers interest who use rahn and ijarah services, and (4) The application of sharia principles, ujrah, and services simultaneously affect the customers interest who use serve rahn and ijarah services.
\end{abstract}

Keywords: syariah principle, ujrah, services, customer interest.

\section{Pendahuluan}

Dinamika ekonomi yang terjadi di dunia tidak jarang mempengaruhi perekonomian di Indonesia. Pergeseran ekonomi kapital justru semakin menyuburkan ekonomi Islam di beberapa Negara. Karakteristrik dari ekonomi Islam salah satunya adalah penerapan prinsip syariah dalam kegiatan perekonomian. Penerapan prinsip syariah ini bukan hanya berlaku pada kegiatan perekonomian saja namun juga objek yang digunakan dalam perekonomian tersebut. Penerapan prinsip syariah sebagai bagian dari ekonomi Islam ini berimbas pada berkembangnya transaksi syariah yang pada akhirnya memunculkan akuntansi syariah.

Perkembangan akuntansi syariah di Indonesia ditandai dengan muncul dan berkembangnya lembaga keuangan bank dan non bank berbasis syariah. Perkembangan ini didukung oleh Undang-Undang meliputi UU no. 7 tahun 1992, UU no. 10 tahun 1998 , UU no. 23 tahun 1999 hingga disahkannya UU no 21 tahun 2008 tentang Perbankan Syariah (Nurhayati dan Wasilah, 2013: 2). Keberadaan undang-undang pendukung berkembangnya lembaga berbasis syariah ini direspon positif oleh masyarakat yang semakin peka terhadap perkembangan permasalahan sosial ekonomi (Rodoni, 2009: 31). Respon positif ini terlihat dari meningkatnya minat masyarakat untuk menggunakan jasa / produk lembaga keuangan baik bank maupun non bank berbasis syariah. Peningkatan minat ini pun semakin mendorong banyaknya pendirian lembaga keuangan bank dan non bank berbasis syariah.

Pegadaian adalah salah satu lembaga keuangan non bank yang dibidik masyarakat untuk membantu kebutuhan pendanaan terutama pemenuhan dana secara cepat. Pegadaian Syariah di Indonesia berkembang cukup baik dimana pada tahun 2014 terdapat 115 kantor cabang Pegadaian Syariah, serta 500 kantor unit pelayanan Cabang Pegadaian Syariah di Indonesia. Produk yang ditawarkan oleh Pegadaian Syariah diantaranya adalah gadai secara syariah (Rahn). Menurut Kasmir (2008:262) gadai adalah kegiatan menjaminkan barang-barang berharga kepada pihak tertentu, guna memperoleh sejumlah uang lalu barang yang dijaminkan akan ditebus kembali sesuai dengan perjanjian antara nasabah dan lembaga gadai. Pada pegadaian syariah transaksi gadai (Rahn) melibatkan 2 (dua) akad sekaligus dan tidak dapat dipisahkan yaitu akad rahn dan akad ijarah.

Nurhayati dan Wasilah (2013: 272) menyatakan bahwa Akad Rahn adalah perjanjian pinjaman dengan jaminan. Selanjutnya barang gadai akan diserahkan kembali kepada pihak yang berhutang apabila hutangnya lunas. Harta sebagai jaminan utang menjadi bayaran sesuai dengan nilai utangnya bila pihak penggadai (Rahin) tidak mampu melunasinya. 
Sedangkan akad ijarah menurut Dewan Standar Akuntansi Syariah (DSK) (2017: 107.1) dalam PSAK 107 adalah akad pemindahan hak guna (manfaat) atas suatu aset dalam kurun waktu tertentu dengan pembayaran sewa (ujrah) tanpa diikuti dengan pemindahan kepemilikan asset tersebut. Dua (2) akad ini melekat pada transaksi gadai syariah dimana akad Rahn untuk mengatur perjanjian pinjaman dengan jaminan, sedangkan akad Ijarah untuk mengatur transaksi sewa tempat penyimpanan barang jaminan atau jasa titipan. Mekanisme pelaksanaan jasa rahn dan ijarah dapat digambarkan sebagai berikut:

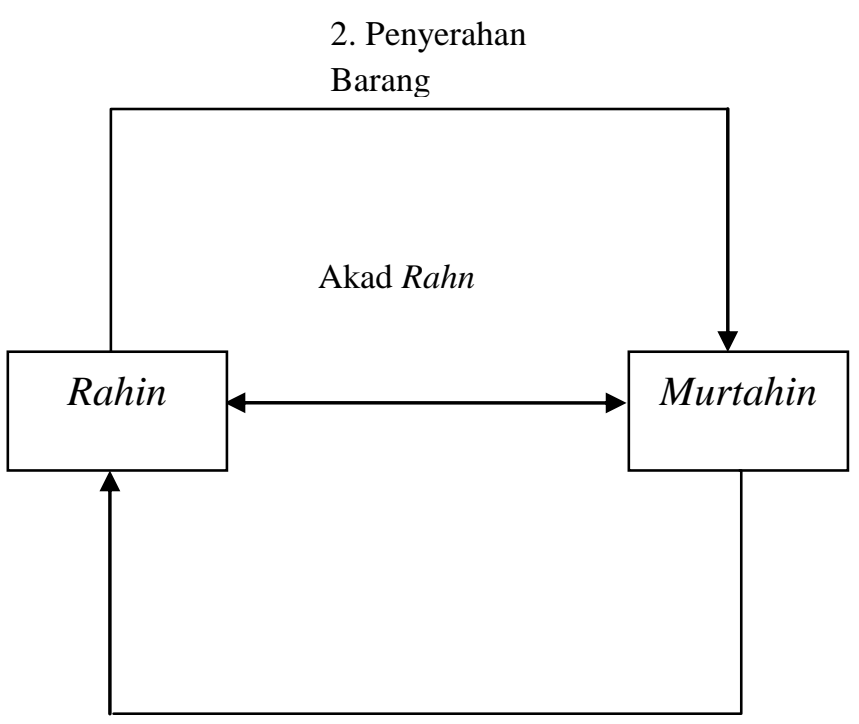

2. Pencairan

Pinjaman

\section{Gambar 1. Skema Rahn}

Sumber : Habiburrahim dkk., (2012)

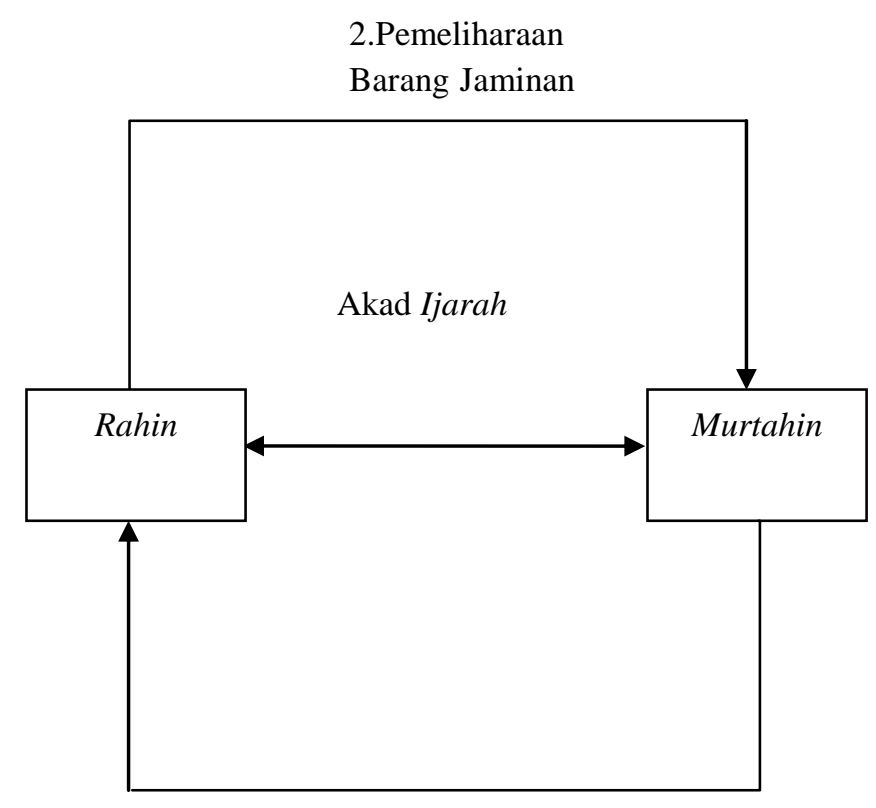

2. Bayar Sewa

\section{Gambar 2. Skema Ijarah}

Sumber : Habiburrahim dkk., (2012)

Seperti halnya lembaga keuangan lain, pegadaian syariah pun juga senantiasa berusaha untuk menarik minat nasabah untuk menggunakan jasa yang ditawarkannya dan akan mempertahankan nasabahnya. Terkait dengan minat nasabah untuk menggunakan jasa pegadaian syariah terutama jasa rahn dan ijarah, faktor yang diduga berpengaruh terhadap minat nasabah adalah ujrah. Akad Ijarah yang melekat pada transaksi gadai syariah (Rahn) menjadi penyebab dikenainya biaya sewa atas tempat penyimpanan barang jaminan yang disebut juga dengan ujrah. Pengenaan Ujrah pada transaksi gadai syariah mungkin tarifnya lebih kecil atau mungkin juga lebih besar dari biaya sewa modal yang dikenakan pada transaksi gadai secara konvensional. Ujrah ini bisa jadi akan mempengaruhi minat masyarakat (nasabah) untuk menggunakan jasa rahn dan ijarah di pegadaian syariah, karena kecenderungan nasabah akan mempertimbangkan biaya yang lebih rendah untuk memperoleh pinjaman dana.

Selain ujrah, faktor lain yang menjadi determinan minat nasabah menggunakan jasa rahn dan ijarah di pegadaian syariah adalah prinsip syariah. Penerapan prinsip syariah penting dalam mengatur cara bertransaksi, kegiatan pelayanan sehari-hari, serta mengatur kegiatan operasional pegadaian syariah. Syariah adalah ketentuan hukum Islam berisi perintah 
dan larangan untuk mengatur kegiatan apapun yang dilakukan oleh manusia serta mengatur hubungan antara sesama manusia (hubungan horizontal) dan hubungan antara manusia dengan Allah (hubungan vertikal). Dewan Standar Akuntansi Keuangan Syariah (2017: 3) menyatakan prinsip syariah meliputi prinsip persaudaraan (Ukhuwah), keadilan ('adalah), kemaslahatan (maslahah), keseimbangan (tawazun), dan universalisme (syumuliyah). Penerapan prinsip syariah oleh pegadaian syariah, akan menjadikan nasabah percaya dan semakin berminat menggunakan jasa rahn dan ijarah. Nasabah pasti akan membandingkan antara prinsip syariah secara ideal dengan realisasinya. Jika operasional pegadaian syariah tidak sesuai dengan prinsip syariah secara ideal dan cenderung lebih memberatkan daripada pegadaian konvensional maka nasabah pun akan berpaling dan tidak memilih jasa rahn dan ijarah yang ditawarkan pegadaian syariah.

Minat nasabah dalam menggunakan jasa rahn dan ijarah pada pegadaian syariah bisa juga dipengaruhi oleh pelayanan yang diberikan pegadaian syariah. Alma (2013: 243) berpendapat bahwa pelayanan pelanggan adalah jasa atau layanan yang diberikan kepada konsumen dalam hubungan dengan produk tertentu. Pelayanan sering menjadi hal yang paling disoroti nasabah pengguna jasa. Fenomena yang sering terjadi bahwa nasabah pengguna jasa seringkali mempermasalahkan pelayanan dari penyedia jasa seperti halnya petugas / karyawan yang tidak ramah, penyelesaian komplain nasabah tidak sampai tuntas, dan lain sebagainya. Pelayanan yang baik adalah pelayanan yang mampu membuat nasabahnya puas dan nyaman. Pelayanan yang memuaskan akan menumbuhkan minat nasabah untuk menggunakan jasa secara berulang. Pelanggan pada dasarnya mencoba untuk membandingkan antara pelayanan yang diperoleh dengan pelayanan yang diharapkan. Bilamana pelayanan yang diperoleh berada di bawah pelayanan yang diharapkan, maka pelanggan menjadi kecewa. Sedangkan jika pelayanan yang diperoleh melebihi pelayanan diharapkan pelanggan cenderung menjadi puas dan akan menggunakan jasa di kemudian hari (Adisaputro, 2010: 187).

Penelitian mengenai faktor yang diduga sebagai determinan minat nasabah pengguna jasa Rahn dan Ijarah ini dilakukan terhadap nasabah kantor Cabang Pegadaian Syariah Madiun. Peneliti ingin mengetahui determinan minat nasabah menggunakan jasa yang disediakan kantor Cabang Pegadaian Syariah Madiun meskipun umur berdirinya pegadaian syariah ini tergolong muda di kota Madiun. Dari latar belakang masalah yang telah dijelaskan di atas maka permasalahan dalam penelitian dirumuskan ke dalam beberapa pertanyaan sebagai berikut:

1. Apakah penerapan prinsip syariah mempengaruhi minat nasabah pengguna jasa Rahn dan Ijarah pada Kantor Cabang Pegadaian Syariah Madiun?

2. Apakah Ujrah mempengaruhi minat nasabah pengguna jasa Rahn dan Ijarah pada Kantor Cabang Pegadaian Syariah Madiun?

3. Apakah Pelayanan mempengaruhi minat nasabah pengguna jasa Rahn dan Ijarah pada Kantor Cabang Pegadaian Syariah Madiun?

Apakah Penerapan prinsip syariah, ujrah, dan pelayanan secara simultan mempengaruhi minat nasabah pengguna jasa Rahn dan Ijarah pada Kantor Cabang Pegadaian Syariah Madiun?.

\section{Kajian Pustaka dan Pengembangan Hipotesis Minat Nasabah}

Slameto (2013: 180) menyampaikan minat adalah suatu rasa lebih suka dan rasa keterikatan pada suatu hal atau aktivitas, tanpa ada yang menyuruh. Nasabah merupakan orang yang biasa berhubungan dengan atau menjadi pelanggan suatu lembaga keuangan (Arif, 2012: 189). Jadi, minat nasabah adalah keinginan nasabah untuk menggunakan suatu produk / jasa lembaga keuangan yang dianggapnya baik dan sesuai dengan kebutuhannya tanpa adanya suatu paksaan. Menurut Ferdinand (dalam Faradiba, 2013: 2) indikator yang dijadikan acuan minat, yaitu sebagai berikut: a. Minat eksploratif, yaitu minat yang menggambarkan perilaku seseorang yang selalu mencari informasi mengenai produk yang diminatinya, b. Minat transaksional, yaitu kecenderungan untuk seseorang untuk membeli produk, c. Minat referensial, yaitu kecenderungan seseorang untuk mereferensikan produk kepada orang lain, d. Minat preferensial, yaitu menggambarkan perilaku seseorang yang memiliki preferensi utama pada produk tersebut. Preferensi hanya dapat diganti jika terjadi sesuatu dengan produk yang dipilihnya. 


\section{Prinsip Syariah}

Syariah berasal dari bahasa Arab yang berarti jalan yang ditempuh atau garis yang seharusnya dilalui (Nurhayati dan Wasilah, 2013: 16). Syariah adalah pokok-pokok aturan hukum yang menuntun umat kepada Allah SWT dengan mengikuti ketetapan-Nya dalam Al-Qur'an dan sunnah Nabi Muhammad, untuk menjalani segala aktivitas kehidupan manusia. Jadi, prinsip syariah adalah suatu keteguhan yang menjadi tuntunan hidup bagi umat manusia dalam segala aspek kehidupannya sesuai dengan pokok-pokok aturan hukum Allah SWT. Syariah tidak hanya mengatur hubungan antara manusia dengan Allah SWT, namun juga mengatur hubungan manusia dengan sesama manusia dan hubungan manusia dengan alam semesta yang didasarkan pada pedoman umat Islam, yaitu AlQur'an dan Hadist. DSAK Syariah (2017: 3) menyebutkan bahwa prinsip syariah meliputi: 1) Prinsip Persaudaraan (Ukhuwah), 2) Prinsip Keadilan ('Adalah), 3) Prinsip Kemaslahatan (Maslahah), 4) Prinsip Keseimbangan (Tawazun), 5) Prinsip Universalisme (Syumuliyah).

Ujrah

Ujrah didefinisikan sebagai imbalan yang diperjanjikan dan dibayar oleh si pengguna jasa atas manfaat yang dinikmati (Nurhayati dan Wasilah, 2013: 246). Pada pelaksanaan akad rahn yang teritegrasi dengan akad ijarah, maka ujrah akan dibayar oleh rahin kepada murtahin atau dengan kata lain ujrah merupakan biaya penyimpanan dan pemeliharaan. Habiburrahim dkk., (2012: 167) mengemukakan bahwa melalui akad ijarah, rahin (nasabah) memberikan biaya jasa (ujrah) kepada murtahin (penerima gadai) apabila masa akad ijarah telah berakhir dan murtahin mengembalikan marhun (barang jaminan) kepada rahin (nasabah). Untuk menghindari riba, maka pengenaan biaya jasa (ujrah) pada barang simpanan nasabah yaitu harus dinyatakan dengan nominal, bukan prosentase, dan sifatnya harus nyata dan jelas, serta tidak terdapat tambahan biaya yang tidak disebutkan di awal.

\section{Pelayanan}

Pelayanan merupakan salah satu bentuk interaksi antara lembaga penyedia produk baik berupa barang ataupun jasa dengan pelaggannya. Pelayanan yang baik dan prima tentu saja menjadi cara lembaga tersebut untuk menarik minat pelanggan/ nasabah menggunakan produknya. Alma (2013: 243) berpendapat bahwa customer service (pelayanan pelanggan) adalah jasa atau layanan yang diberikan kepada konsumen dalam hubungan dengan produk tertentu. Tjiptono (2006: 273) mengatakan pelayanan yang berkualitas tentu saja memiliki dimensi utama meliputi: 1) Reliabilitas (reliability); 2) Daya tanggap (responsiveness); 3) Jaminan (assurance); 4) Empati (empathy); 5) Bukti fisik (tangibles).

Jadi dapat disimpulkan pelayanan yaitu sikap atau tindakan dari lembaga yang diwakili oleh karyawan sebagai bentuk interaksi dengan nasabah. Pelayanan bertujun untuk membuat nasabah merasa puas terhadap pelayanan yang diberikan sehingga nasabah percaya dan nyaman menggunakan produk/ jasa dari lembaga yang dalam penelitian adalah pegadaian syariah. Baik buruknya pelayanan yang diberikan kepada nasabah akan berimbas pada ketertarikan / minat nasabah menggunakan produk/ jasa pegadaian syariah.

Berangkat dari teori serta logika pemikiran yang telah dijabarkan di atas maka penelitian ini mengajukan beberapa hipotesis sebagai berikut:

H1 : Prinsip syariah mempengaruhi minat nasabah pengguna jasa Rahn dan Ijarah pada Kantor Cabang Pegadaian Syariah Madiun.

$\mathrm{H} 2 \quad$ : Ujrah mempengaruhi minat nasabah pengguna jasa Rahn dan Ijarah pada Kantor Cabang Pegadaian Syariah Madiun.

H3 : Pelayanan mempengaruhi minat nasabah pengguna jasa Rahn dan Ijarah pada Kantor Cabang Pegadaian Syariah Madiun.

H4 : Penerapan prinsip syariah, ujrah, dan pelayanan secara simultan mempengaruhi minat nasabah pengguna jasa Rahn dan Ijarah pada Kantor Cabang Pegadaian Syariah Madiun.

\section{Metode Penelitian}

\section{Jenis dan Desain Penelitian}

Penelitian dilaksanakan dengan metode kuantitatif serta desain hubungan kausalitas untuk mengetahui pengaruh variabel $\mathrm{X}$ terhadap variabel $\mathrm{Y}$. Metode kuantitatif yaitu metode yang digunakan untuk meneliti pada populasi atau sampel tertentu, pengumpulan data menggunakan instrumen tertulis, analisis data bersifat kuantitatif statistik dengan tujuan 
tertentu untuk menguji hipotesis yang telah ditetapkan (Sugiyono, 2014: 11). Menurut Sugiyono (2013: 63) hubungan kasual adalah hubungan sebab akibat. Desain penelitian yang dilaksanakan dapat digambarkan sebagai berikut:

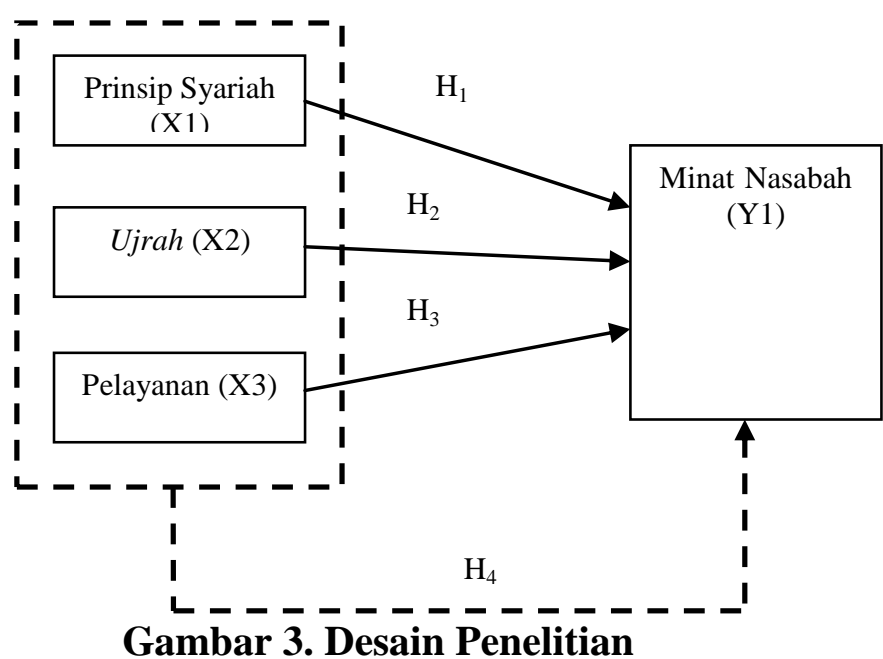

Populasi, Sampel, dan Teknik Sampling

Populasi sebesar 793 nasabah adalah seluruh nasabah jasa rahn dan ijarah terhitung bulan April 2010 sampai bulan Maret 2016 di Cabang Pegadaian Syariah Madiun. Teknik pengambilan sampel menggunakan teknik sampling insidental. Menurut Sugiyono (2013: 126) sampling insidental adalah teknik penentuan sampel berdasarkan kebetulan yaitu siapa saja yang secara kebetulan/insidental bertemu dengan peneliti dapat digunakan sebagai sampel, bila dipandang orang yang kebetulan ditemui itu cocok sebagai sumber data. Dari teknik sampling insidental ini diperoleh sampel sebesar 227 sampel yang akan dijadikan responden.

\section{Teknik Pengumpulan Data}

Penelitian ini memanfaatkan teknik wawancara serta kuesioner dalam pengumpulan data. Arikunto (2013: 198) menjelaskan bahwa wawancara adalah percakapan yang dilakukan oleh pewawancara (interviewer) dengan menggunakan pertanyaan pertanyaan untuk memperoleh informasi dari terwawancara (interviewee). Teknik wawancara digunakan untuk memperoleh informasi awal mengenai bagaimana minat nasabah dan hal apa saja yang mempengaruhi minat nasabah menggunakan jasa rahn dan ijarah. Wawancara ini dilakukan terhadap kepala cabang pegadaian syariah madiun, karyawan serta nasabah Cabang Pegadaian Syariah Madiun.

Sugiyono (2013: 193) mendefinisikan kuesioner sebagai teknik pengumpulan data yang dilakukan dengan cara memberikan seperangkat pertanyaan atau pernyataan tertulis kepada responden untuk dijawabnya. Kuesioner ini untuk memperoleh data mengenai minat nasabah, serta faktor yang diduga sebagai determinannya yang meliputi penerapan prinsip syariah, ujrah, dan pelayanan.

\section{Definisi Operasional Variabel}

Variabel pada penelitian ini terdiri dari tiga (3) variabel independen (bebas) dan satu (1) variabel dependen (terikat). Tiga Variabel independen tersebut adalah:

a. Prinsip syariah adalah suatu keteguhan yang menjadi tuntunan hidup bagi umat manusia dalam segala aspek kehidupannya sesuai dengan pokok-pokok aturan hukum Allah SWT. Prinsip syariah ini meliputi prinsip persaudaraan (Ukhuwah), keadilan ('adalah), kemaslahatan (maslahah), keseimbangan (tawazun), dan universalisme (syumuliyah).

b. Ujrah adalah biaya penyimpanan dan pemeliharaan terhadap marhun (barang jaminan).

c. Pelayanan adalah merupakan salah satu bentuk interaksi antara lembaga penyedia produk baik berupa barang ataupun jasa dengan pelanggannya.

Sedangkan variabel dependen pada penelitian ini adalah variabel minat nasabah pengguna jasa rahn dan ijarah. Minat nasabah didefinisikan sebagai keinginan nasabah untuk menggunakan suatu produk / jasa lembaga keuangan yang dianggapnya baik dan sesuai dengan kebutuhannya tanpa adanya suatu paksaan.

\section{Teknik Analisis Data}

Data dalam penelitian ini dianalisis dengan analisis regresi berganda. Namun sebelumnya perlu dilakukan uji keabsahan data mengingat data mengenai minat nasabah serta faktor yang mempengaruhinya diperoleh dengan instrument berupa kuesioner. Setelah itu dilakukan uji asumsi klasik untuk selanjutnya dapat dilakukan analisis regresi berganda.

\section{a. Uji Keabsahan Data}

\section{Uji Validitas}

Uji validitas dilakukan untuk memastikan bahwa instrument dapat digunakan untuk 
mengukur apa yang seharusnya diukur (Sugiyono, 2013: 168). Kriteria pengujiannya adalah jika $r$ hitung lebih besar dari $r$ table dan nilai positif maka butir atau pertanyaan atau indikator tersebut dinyatakan valid.

\section{Uji Reliabilitas}

Uji validitas dilakukan untuk memastikan bahwa kuesioner reliabel. Menurut Ghozali (2013: 47) suatu kuesioner dikatakan reliabel atau handal jika jawaban seseorang terhadap pernyataan adalah konsisten atau stabil dari waktu ke waktu. Kriteria pengujiannya adalah jika nilai Cronbach Alpha > 0,70.

\section{b. Uji Asumsi Klasik}

Uji asumsi klasik dilakukan karena penggunaan model analisis regresi berganda terikat dengan sejumlah asumsi dan harus memenuhi asumsiasumsi klasik yang mendasari model tersebut. Uji asumsi klasik ini meliputi:

1. Uji Normalitas

Uji normalitas bertujuan untuk menguji apakah dalam model regresi, variabel pengganggu atau residual memiliki distribusi normal (Ghozali, 2013: 160). Pengujian dengan One Sample Kolmogorov Smirnov. Kriteria pengujian, yaitu jika Signifikansi > 0,05 maka data distribusi normal, dan jika signifikansi < 0,05 maka data tidak berdistribusi normal (Priyatno, 2013: 26).

2. Uji Autokorelasi

Uji autokorelasi bertujuan menguji apakah dalam model regresi linear ada korelasi antara kesalahan pengganggu pada periode $t$ dengan kesalahan pengganggu pada periode $\mathrm{t}-1$ (sebelumnya) (Ghozali, 2013: 110). Kriteria pengujian, yaitu jika nilai $\mathrm{dU}<\mathrm{d}<4-\mathrm{Du}$ maka model penelitian terbebas dari autokorelasi.

3. Uji Multikolinearitas

Uji multikolinieritas bertujuan untuk menguji apakah model regresi ditemukan adanya korelasi antar variabel bebas (independen) (Priyatno, 2013: 59). Kriteria pengujian, yaitu jika nilai tolerance $\geq 0,10$ atau sama dengan nilai $\mathrm{VIF} \leq 10$ maka model regresi terbebas dari multikolinearitas.
4. Uji Heteroskedastisitas

Uji Heteroskedastisitas bertujuan untuk menguji apakah dalam model regresi terjadi ketidaksamaan variance dari residual satu pengamatan ke pengamatan yang lain Priyatno (2013: 60). Peneliti menggunakan Scatterplott untuk menentukan ada tidaknya masalah heteroskedastisitas. Kritera pengujian jika titik - titik menyebar tanpa membentuk pola khusus maka dalam model penelitian terbebas dari heteroskedastisitas.

c. Analisis Regresi Linier Berganda dan Pengujian Hipotesis

Untuk melakukan analisis regresi linier berganda maka dapat dituliskan persamaan sebagai berikut: $\mathrm{Y}=\mathrm{b} 0+\mathrm{b} 1 \mathrm{X} 1+\mathrm{b} 2 \mathrm{X} 2+\mathrm{b} 3 \mathrm{X} 3$

(Priyatno, 2013: 47)

Keterangan:

$\mathrm{Y} \quad=$ minat nasabah

$\mathrm{X}_{1} \quad$ = prinsip syariah

$\mathrm{X}_{2} \quad=$ Ujrah

$\mathrm{X}_{3} \quad=$ pelayanan

$\mathrm{b}_{0} \quad=$ Konstanta,

$\mathrm{b} 1, \mathrm{~b} 2, \mathrm{~b} 3=$ Koefisien Regresi

Selanjutnya pengujian hipotesis menggunakan uji statistik $\mathrm{t}$ untuk mengetahui pengaruh secara parsial variabel independen terhadap variabel dependen (Priyatno, 2013: 50). Sedangkan uji statistik $\mathrm{F}$ untuk mengetahui pengaruh variabel independen secara simultan terhadap variabel dependen. Kemudian untuk mengetahui seberapa besar prosentase sumbangan pengaruh variabel independen secara serentak terhadap variabel dependen dilihat nilai koefisien determinasi $\left(\mathrm{R}^{2}\right)$, namun penelitian ini menggunakan nilai adjusted $R^{2}$ karena kelemahan dalam penggunaan koefisien determinasi adalah bias terhadap jumlah variabel independen yang dimasukkan ke dalam model (Ghozali, 2013: 97).

\section{Hasil dan Pembahasan}

\section{a. Uji Keabsahan Data}

\section{Uji Validitas}

Uji validitas untuk memastikan valid tidaknya suatu instrument. Kriteria pengujiannya adalah jika $r$ hitung lebih besar dari $r$ table dan nilai positif maka butir pertanyaan atau 
pernyataan atau indikator tersebut dinyatakan valid.

Tabel 1.Hasil Uji Validitas

\begin{tabular}{ccccc}
\hline Variabel & Item & $\begin{array}{c}\text { Corrected } \\
\text { item Total } \\
\text { Correlation }\end{array}$ & $\begin{array}{c}\text { Nilai r } \\
\text { Tabel }\end{array}$ & Hasil \\
& 1 & 0,601 & 0,109 & Valid \\
Prinsip & 2 & 0,665 & 0,109 & Valid \\
Syariah & 3 & 0,721 & 0,109 & Valid \\
(X1) & 4 & 0,687 & 0,109 & Valid \\
& 5 & 0,694 & 0,109 & Valid \\
& 6 & 0,720 & 0,109 & Valid \\
& 1 & 0,821 & 0,109 & Valid \\
Ujrah & 2 & 0,685 & 0,109 & Valid \\
(X2) & 3 & 0,636 & 0,109 & Valid \\
& 4 & 0,678 & 0,109 & Valid \\
& 5 & 0,684 & 0,109 & Valid \\
& 6 & 0,517 & 0,109 & Valid \\
Pelayanan & 1 & 0,556 & 0,109 & Valid \\
(X3) & 2 & 0,692 & 0,109 & Valid \\
& 3 & 0,603 & 0,109 & Valid \\
& 4 & 0,302 & 0,109 & Valid \\
& 5 & 0,639 & 0,109 & Valid \\
Minat & 6 & 0,528 & 0,109 & Valid \\
Nasabah & 1 & 0,571 & 0,109 & Valid \\
& 2 & 0,500 & 0,109 & Valid \\
& 3 & 0,505 & 0,109 & Valid \\
& 4 & 0,607 & 0,109 & Valid \\
& 5 & 0,625 & 0,109 & Valid \\
& 6 & 0,698 & 0,109 & Valid \\
\hline
\end{tabular}

Dari tabel 1. Hasil uji validitas menunjukkan bahwa semua item untuk masing-masing pernyataan memiliki nilai $\mathrm{r}$ ( $\mathrm{r}$ hitung) lebih besar dari $r$ tabel ( $r$ hitung $>\mathrm{r}$ tabel). Jadi dapat disimpulkan bahwa item pernyataan dalam kuesioner valid.

\section{Uji Reliabilitas}

Untuk mengetahui keandalan (konsistensi) instrumen (alat ukur) berupa kuesioner dapat dilihat dari hasil uji reliabilitas yaitu nilai cronbach's alpha. Suatu konstruk atau variabel dikatakan reliabel jika memberikan nilai Cronbach Alpha >0,70.
Tabel 2. Hasil Uji Reliabilitas

\begin{tabular}{clcc}
\hline No & \multicolumn{1}{c}{ Varibel } & $\begin{array}{c}\text { Cronbach } \\
\text { Alpha }\end{array}$ & Hasil \\
& & 0,877 & Reliabel \\
\hline 1 & Prinsip Syariah & 0,877 & \\
& $($ X1) & 0,869 & Reliabel \\
2 & Ujrah (X2) & 0,793 & Reliabel \\
3 & Pelayanan (X3) & 0,816 & Reliabel \\
4 & Minat Nasabah & \\
& $($ Y) & \\
\hline \multicolumn{4}{c}{ Tabel 2. Di atas menunjukkan bahwa nilai } \\
Cronbach Alpha untuk seluruh variabel lebih \\
besar (>) dari 0,70. Ini berarti konstruk atau \\
variabel dikatakan reliabel.
\end{tabular}

\section{b. Uji Asumsi Klasik}

1. Normalitas

Uji normalitas dilakukan dengan one sample kolmogorov smirnov dan hasilnya adalah sebagai berikut:

Tabel 3. Hasil Uji Normalitas

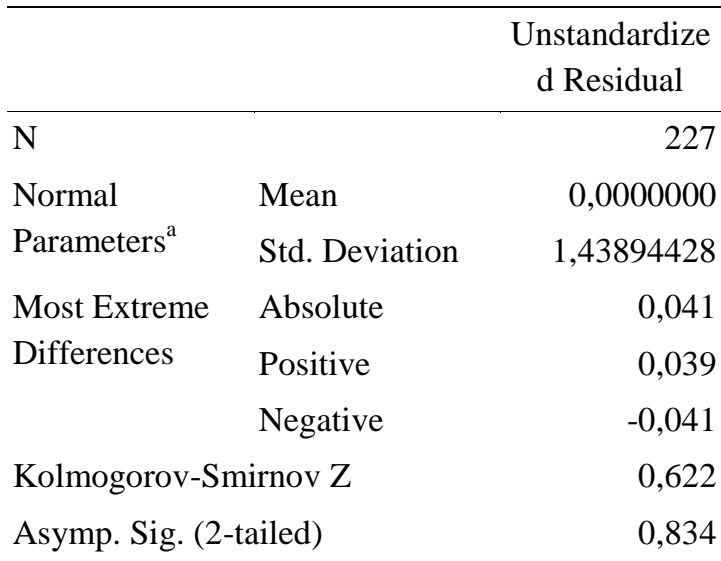

Tabel 3 memperlihatkan nilai Assymp Sig 0,834 . Nilai ini lebih besar dari $0,05(0,834$ > $0,05)$ yang berarti data penelitian terdistribusi secara normal.

\section{Uji Autokorelasi}

Peneliti melakukan uji Durbin Watson untuk mendeteksi ada tidaknya masalah autokorelasi pada model penelitian. 
Tabel 4. Hasil Uji Autokorelasi

\begin{tabular}{|c|c|c|c|c|}
\hline $\begin{array}{c}\text { Keteranga } \\
\mathbf{n}\end{array}$ & $\overline{D_{u}}$ & Dw & $\overline{4-d_{U}}$ & $\begin{array}{c}\text { Keteranga } \\
\text { n }\end{array}$ \\
\hline Nilai & $\begin{array}{l}1,79 \\
9\end{array}$ & $\begin{array}{l}1,96 \\
8\end{array}$ & $\begin{array}{l}2,20 \\
1\end{array}$ & $\begin{array}{l}\text { Tidak } \\
\text { terdapat } \\
\text { autokorelas } \\
\text { i }\end{array}$ \\
\hline
\end{tabular}

Tabel 4 di atas menunjukkan bahwa pada model penelitian tidak terdapat masalah autokorelasi nilai Durbin Watson memenuhi kriteria $\mathrm{Du}<\mathrm{DW}<4$-DU.

\section{Uji Multikolinearitas}

Uji multikolonieritas bertujuan untuk menguji apakah model regresi ditemukan adanya korelasi antar variabel bebas (independen). Kriteria pengujiannya jika Nilai tolerance < 0,10 dan nilai VIF > 10 maka dikatakan bahwa ada multikokonieritas.

Tabel 5. Hasil Uji Multikolinearitas

\begin{tabular}{cccl}
\hline $\begin{array}{c}\text { Variabel } \\
\text { independ } \\
\text { en }\end{array}$ & $\begin{array}{c}\text { Toleran } \\
\text { ce }\end{array}$ & VIF & Keterangan \\
\hline X1 & 0,769 & 1,300 & $\begin{array}{l}\text { Tidak terjadi } \\
\text { multikolonierit } \\
\text { as }\end{array}$ \\
& & & $\begin{array}{l}\text { Tidak terjadi } \\
\text { multikolonierit } \\
\text { as }\end{array}$ \\
& 0,776 & 1,288 & \\
X3 & & & $\begin{array}{l}\text { Tidak terjadi } \\
\text { multikolonierit } \\
\text { as }\end{array}$ \\
& 0,971 & 1,030 & \\
& & & \\
\hline
\end{tabular}

Tabel 5 menunjukkan bahwa semua nilai tolerance di atas 0,01 sedangkan nilai VIF di bawah 10. Jadi dapat disimpulkan bahwa tidak terjadi korelasi antar variabel bebas (independen) dalam model penelitian.

\section{Heteroskedastisitas}

Uji heteroskedastisitas bertujuan menguji apakah dalam model regresi terjadi ketidaksamaan variance dari residual satu pengamatan ke pengamatan yang lain. Berikut hasil Scatterplot.

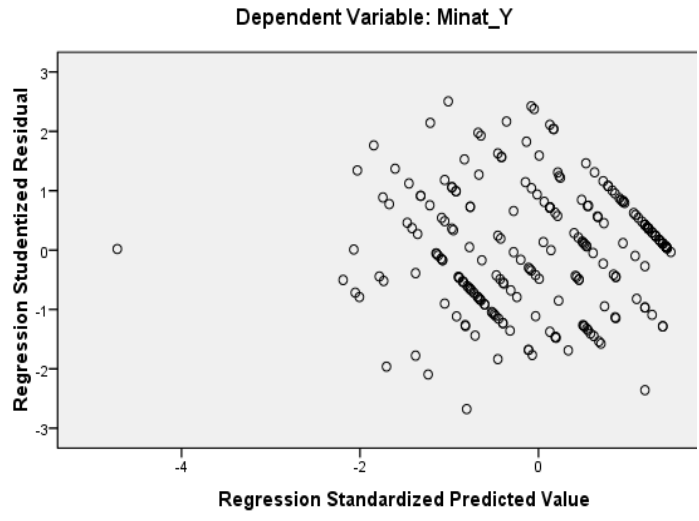

\section{Gambar 3.Scatterplot}

Dari gambar 3 dapat dilihat bahwa titik menyebar tanpa membentuk pola secara khusus. Jadi dapat disimpulkan pada model regresi tidak terjadi masalah heteroskedastisitas.

\section{c. Analisis Regresi Linier Berganda dan} Pengujian Hipotesis

Tabel di bawah ini merupakan hasil olah data untuk mendukung dilakukannya analisis regresi berganda.

Tabel 6. Hasil Analisis Regresi Berganda

\begin{tabular}{llll}
\hline \multirow{2}{*}{ Model } & \multicolumn{2}{l}{ Unstandardized Coefficients } \\
& B & Std. Error \\
\hline 1 & (Constant) & 5,008 & 1,245 \\
& Prinsip & & \\
& Syariah & 0,110 & 0,042 \\
& Ujrah & $-0,019$ & 0,036 \\
& Pelayanan & 0,740 & 0,033 \\
\hline
\end{tabular}

Jika nilai B di atas dimasukan ke dalam model penelitian, maka diperoleh persamaan sebagai berikut:

$Y=5,008+0,110 X_{1}-0,019 X_{2}+0,740 X_{3}$

Penjabaran dari persamaan tersebut nilai konstanta sebesar 5,008 artinya tanpa adanya pengaruh variabel prinsip syariah, ujrah, dan pelayanan, maka minat nasabah pengguna jasa rahn dan ijarah akan tetap sebesar 5,008. Nilai koefisien regresi untuk X1 (prinsip syariah) senilai 0,110 berarti bahwa apabila terjadi peningkatan variabel prinsip syariah sebesar satu satuan maka minat nasabah pengguna jasa rahn dan ijarah akan naik sebesar 0,110 satuan dengan asumsi variabel lain tetap. Koefisien regresi untuk X2 (ujrah) senilai - 0,019 berarti apabila terjadi 
peningkatan variabel ujrah sebesar satu satuan maka minat nasabah pengguna jasa rahn dan ijarah akan turun sebesar 0,019 satuan dengan asumsi variabel lain tetap. Koefisien regresi untuk X3 (pelayanan) senilai 0,740 berarti apabila terjadi peningkatan variabel pelayanan sebesar satu satuan maka minat nasabah pengguna jasa rahn dan ijarah akan naik sebesar 0,740 satuan dengan asumsi variabel lain tetap.

Selanjutnya disajikan tabel hasil uji hipotesis dengan uji statistik $\mathrm{t}$ dan uji statistik $\mathrm{F}$, serta analisis koefisien determinasi.

Tabel 7. Hasil Analisis Koefisien Determinasi

\begin{tabular}{cccc}
\hline Model & R & R Square & $\begin{array}{c}\text { Adjusted R } \\
\text { Square }\end{array}$ \\
\hline 1 & $0,844^{\mathrm{a}}$ & 0,713 & 0,709 \\
\hline
\end{tabular}

Dari tabel tersebut diketahui bahwa nilai Adjusted $R$ Square sebesar 0,709 artinya variabel minat nasabah pengguna jasa rahn dan ijarah dapat dijelaskan oleh variabel prinsip syariah, ujrah, dan pelayanan sebesar $70,9 \%$, sisanya sebesar $29,1 \%$ dijelaskan oleh variabel lain di luar model penelitian.

Uji statistik t dilakukan untuk mengetahui pengaruh parsial variabel independen terhadap variabel dependen. Dari tabel yang disajikan berikut akan diketahui variabel yang berpengaruh dan yang tidak berpengaruh terhadap minat nasabah pengguna jasa Rahn dan Ijarah.

Tabel 8. Hasil Uji Statistik t

\begin{tabular}{cccc}
\hline & Model & $\mathrm{t}$ & Sig. \\
\hline 1 & (Constant) & 4,024 & 0,000 \\
& Prinsip Syariah & 2,589 & 0,010 \\
& Ujrah & $-0,525$ & 0,600 \\
& Pelayanan & 22,657 & 0,000 \\
\hline
\end{tabular}

Tabel di atas menunjukkan bahwa dari ketiga variabel independen terdapat 2 (dua) variabel yang berpengaruh terhadap minat nasabah pengguna jasa Rahn dan Ijarah yaitu variabel prinsip syariah dan pelayanan. Prinsip syariah memiliki nilai signifikansi 0,010 , nilai tersebut lebih kecil dari $0,05(0,010<$ $0,05)$. Hipotesis 1 (H1) yang menyatakan prinsip syariah mempengaruhi minat nasabah pengguna jasa Rahn dan Ijarah pada Kantor Cabang Pegadaian Syariah Madiun, diterima. Penerapan prinsip syariah ada operasional pegadaian syariah yang ideal akan memunculkan kepercayaan nasabah dan bahkan calon nasabah. Jika pegadaian syariah mampu mempertahankan kepercayaan nasabah dengan menegakkan prinsip syariah dalam operasionalnya maka nasabah akan semakin berulang menggunakan jasa pegadaian syariah. Penggunaan jasa yang berulang mencerminkan minat nasabah dalam menggunakan jasa pegadaian syariah.

Variabel ujrah memiliki nilai signifikansi 0,600 , nilai tersebut lebih besar dari $0,05(0,600>$ 0,05). Hipotesis 2 (H2) yang menyatakan ujrah mempengaruhi minat nasabah pengguna jasa Rahn dan Ijarah pada Kantor Cabang Pegadaian Syariah Madiun, ditolak. Ujrah tidak berpengaruh terhadap minat nasabah pengguna jasa Rahn dan Ijarah, karena pada umumnya melakukan kegiatan menggadai dengan alasan kebutuhan yang mendesak. Sehingga karena alasan yang mendesak tersebut, kadang membuat nasabah kurang memperhatikan besar kecilnya biaya penyimpanan dan pemeliharaan (ujrah).

Variabel pelayanan memiliki nilai signifikansi 0,000 , nilai tersebut lebih kecil dari $0,05(0,000<$ $0,05)$. Hipotesis $3(\mathrm{H} 3)$ yang menyatakan pelayanan mempengaruhi minat nasabah pengguna jasa Rahn dan Ijarah pada Kantor Cabang Pegadaian Syariah Madiun.

Uji statistik $\mathrm{F}$ dilakukan untuk mengetahui pengaruh variabel independen secara simultan. Dari tabel yang disajikan berikut akan diketahui apakah secara simultan variabel independen berpengaruh ataukah tidak terhadap minat nasabah pengguna jasa Rahn dan Ijarah.

\section{Tabel 10. Hasil uji statistik F}

\begin{tabular}{llcc}
\hline & Model & F & Sig. \\
\hline 1 & Regression & 184,777 & $0,000^{\mathrm{b}}$ \\
& Residual \\
& & \\
\hline
\end{tabular}

Dari tabel di atas diketahui bahwa $\mathrm{F}$ hitung > Ftabel yaitu $184,777>2,60$ serta nilai signifikansi sebesar 0,000. Nilai itu lebih kecil dari 0,05 $(0,000<$ $0,05)$ sehingga hipotesis 4 (H4) yang menyatakan Penerapan prinsip syariah, ujrah, dan pelayanan secara simultan mempengaruhi minat nasabah pengguna jasa Rahn dan Ijarah pada Kantor Cabang Pegadaian Syariah Madiun, diterima. 


\section{Simpulan}

Berdasarkan hasil penelitian yang telah dijabarkan dapat disimpulkan sebagai berikut:

1. Prinsip syariah mempengaruhi minat nasabah pengguna jasa Rahn dan Ijarah pada Kantor Cabang Pegadaian Syariah Madiun. Jika operasional pegadaian syariah tidak sesuai dengan prinsip syariah secara ideal dan cenderung lebih memberatkan daripada pegadaian konvensional maka nasabah pun akan berpaling dan tidak memilih jasa rahn dan ijarah yang ditawarkan pegadaian syariah.

2. Ujrah mempengaruhi minat nasabah pengguna jasa Rahn dan Ijarah pada Kantor Cabang Pegadaian Syariah Madiun. Nasabah melakukan kegiatan menggadai dengan alasan kebutuhan yang mendesak. Sehingga karena alasan yang mendesak tersebut, kadang membuat nasabah kurang memperhatikan besar kecilnya biaya penyimpanan dan pemeliharaan (ujrah).

3. Pelayanan mempengaruhi minat nasabah pengguna jasa Rahn dan Ijarah pada Kantor Cabang Pegadaian Syariah Madiun. Pelayanan yang memuaskan akan menumbuhkan minat nasabah untuk menggunakan jasa secara berulang.

4. Penerapan prinsip syariah, ujrah, dan pelayanan secara simultan mempengaruhi minat nasabah pengguna jasa Rahn dan Ijarah pada Kantor Cabang Pegadaian Syariah Madiun.

\section{SARAN}

1. Bagi Kantor Cabang Pegadaian Syariah Madiun Penelitian menunjukkan bahwa dari ketiga variabel yang menjadi determinan minat nasabah, variabel yang paling dominan adalah pelayanan. Saran yang dapat diberikan adalah Kantor Cabang Pegadaian Syariah Madiun sebaiknya mempertahankan dan bahkan meningkatkan pelayanan yang diberikan dengan memperbaiki fasilitas dan peralatan fisik, memberikan jasa secara akurat, andal, petugas memiliki sikap tanggap, berpengetahuan dan memberikan empati kepada nasabahnya. Tentu saja pemberian pelayanan ini juga dengan tetap memperhatikan penerapan prinsip syariah pada setiap operasional perusahaan.
2. Bagi penelitian berikutnya

Penelitian selanjutnya dapat menambahkan variabel yang juga diduga sebagai determinan minat nasabah seperti halnya promosi, produk, kepercayaan, keberadaan alternatif penyedia jasa sejenis lainnya. Penelitian selanjutnya dapat memperluas area penelitian di ekskarisidenan Madiun.

\section{Referensi}

[1] Adisaputro, G. 2010. Manajemen Pemasaran: Analisis Untuk Perancangan Strategi Pemasaran. Yogyakarta: UPP STIM YKPN.

[2] Alma, B. 2013. Manajemen Pemasaran dan Pemasaran Jasa. Bandung: Alfabeta.

[3] Arif, M. Nur Rianto Al. 2012. Dasar-Dasar Pemasaran Bank Syariah. Bandung: Alfabeta.

[4] Arikunto, S. 2013. Prosedur Penelitian Suatu Pendekatan Praktik. Jakarta: Rineka Cipta.

[5] Dewan Standar Akuntansi Keuangan Syariah. 2017. PSAK Syariah. Jakarta: Ikatan Akuntan Indonesia.

[6] Faradiba dan Astuti Sri Rahayu Tri. 2013. Analisis Pengaruh Kualitas Produk, Harga, Lokasi, Dan Kualitas Pelayanan Terhadap Minat Beli Ulang Konsumen. Jurnal DJOM (Online), Vol 2, No. 3, (http://ejournals1.undip.ac.id, Diunduh 31 Mei 2017).

[7] Ghozali, I. 2013. Aplikasi Analisis Multivariate dengan Program SPSS 21. Semarang: UNDIP.

[8] Habiburrahim, Rahmawati, Suhardjo, Budiyana, dan Wartono. 2012. Mengenal Pegadaian Syariah. Jakarta Timur: Kuwais.

[9] Kasmir. 2008. Bank dan Lembaga Keuangan Lainnya. Jakarta: RajaGrafindo Persada.

[10] Nurhayati, S. dan Wasilah. 2013: Akuntansi Syariah di Indonesia. Jakarta: Salemba Empat.

[11] Priyatno, D. 2013. Analisis Korelasi, Regresi, dan Multivariate dengan SPSS. Yogyakarta: Gava Media.

[12] Rodoni, Ahmad. 2009. Investasi Syariah. Jakarta: Lembaga Penelitian UIN Jakarta.

[13] Slameto. 2013. Belajar dan Faktor-Faktor Yang Mempengaruhi. Jakarta: Rineka Cipta.Arif, 2012 
[14] Sugiyono. 2013. Metode Penelitian Kuantitatif, Kualitatif, dan Kombinasi (Mixed Methods). Bandung: Alfabeta.

[15] Tjiptono, F. 2006. Strategi Bisnis. Yogyakarta: Andi Offset.

[16] Wulansari, F. 2015. Faktor-Faktor Yang Mempengaruhi Masyarakat Terhadap Jasa Rahn Pada Pegadaian Syariah Singkawang, Jurnal Untan (Online), Vol. 4, No. 4,(http://jurnal.untan.ac.id/index.php.jcc/.artic le/view/11582/10916 diunduh tanggal 23 Maret 2017). 